\title{
Erythrocyte Sedimentation Rate May Predict Diagnosis of Lymphoma Without Fine-needle Aspiration Biopsy: A Retrospective Study
}

\author{
Eritrosit Sedimantasyon Hızı İnce İğne Aspirasyon Biyopsisi Olmadan \\ Lenfoma Tanısını Öngörebilir: Retrospektif Bir Çalışma
}

\author{
(D) Esra Turan Erkek1, (D) Oğuz Firat Bozkurt2, (D Melis Demirağ Evman³ \\ ${ }^{1}$ Kartal Dr. Lütfi Kurdar Training and Research Hospital, Clinic of Hematology, İstanbul, Turkey \\ ${ }^{2}$ Kartal Dr. Lütfi Kurdar Training and Research Hospital, Clinic of Internal Medicine, İstanbul, Turkey \\ ${ }^{3}$ Kartal Dr. Lütfi Kırdar Training and Research Hospital, Clinic of Otorhinolaryngology-Head and Neck Surgery, İstanbul, Turkey
}

\section{Abstract}

Objective: To assess the relationship between routine blood values recorded before fine-needle aspiration biopsy (FNAB) and final diagnosis in patients whose diagnoses could not be confirmed with FNAB, necessitating surgical excisional biopsy (SEB) as a second invasive procedure.

Method: The data of patients who could not be diagnosed via FNAB and who underwent SEB of the cervical lymph node between March 2014 and March 2019 in the otolaryngology department of a research hospital were evaluated retrospectively. According to the definitive diagnosis determined by SEB, the cases were divided into 3 groups as follows: 1) benign, 2) other malignancies, 3) lymphoma.

Results: The frequency of males in the other malignancies group was significantly higher compared to the other two groups $(p=0.007)$. Compared to the other two groups, $\mathrm{C}$-reactive protein levels were statistically significantly lower in the benign group $(p=0.001)$. Erythrocyte sedimentation rate (ESR) in the lymphoma group was significantly higher than in the other groups $(p<0.001)$ and ESR was found to have $70.21 \%$ sensitivity, $75.76 \%$ specificity and $73.97 \%$ accuracy to discriminate lymphoma from other tumors with a cut-off point of $>35.5 \mathrm{~mm} / \mathrm{hr}$ (area under the curve $=0.784,95 \%$ confidence interval: 0.708-0.861, $p<0.001$ ).

Conclusion: Although ESR is non-specific for the diagnosis of lymphoma in asymptomatic patients, it may be a supportive marker to reduce repetitive invasive procedures in symptomatic patients who may require cervical lymph node biopsy for diagnosis.

Keywords: C-reactive protein, erythrocyte sedimentation rate, fineneedle aspiration biopsy, lymphoma

\section{öz}

Amaç: İnce iğne aspirasyon biyopsisi (iiAB) ile tanısı doğrulanamayan ve ikinci bir invaziv işlem olarak cerrahi eksizyonel biyopsi (CEB) gerektiren hastalarda iiAB öncesi kaydedilen rutin kan değerleri ile kesin tanı arasındaki ilişkiyi değerlendirmektir.

Yöntem: Bir araştırma hastanesinin kulak burun boğaz kliniğinde Mart 2014-Mart 2019 tarihleri arasında IïAB ile tanı konamayan ve servikal lenf nodu CEB yapılan hastaların verileri retrospektif olarak değerlendirildi. CEB'ye göre belirlenen kesin tanıya göre olgular şu şekilde 3 gruba ayrıldı: 1) benign, 2) diğer maligniteler, 3) lenfoma.

Bulgular: Diğer maligniteler grubundaki erkeklerin sıklığı diğer iki gruba göre anlamlı olarak daha yüksekti $(p=0,007)$. Diğer iki grupla karşılaştıııldığında, C-reaktif protein seviyeleri benign grupta istatistiksel olarak anlamlı düzeyde daha düşüktü $(p=0,001)$. Lenfoma grubunda eritrosit sedimantasyon hızı (ESR) diğer gruplara göre anlamlı düzeyde daha yüksekti $(p<0,001)$ ve lenfomayı diğer tümörlerden ayırmada ESR'nin $>35,5 \mathrm{~mm} /$ saat kesim noktasında \%70,21 duyarlılık, \%75,76 özgüllük ve \%73,97 doğruluğa sahip olduğu saptandı (eğri altındaki alan =0,784, \%95 güven aralığı: 0,708-0,861, $p<0,001$ ).

Sonuç: ESR, asemptomatik hastalarda lenfoma tanısı için spesifik olmasa da, tanı için servikal lenf nodu biyopsisine ihtiyaç duyan semptomatik hastalarda tekrarlayan invazif prosedürleri azaltmak için destekleyici bir belirteç olabilir.

Anahtar kelimeler: C-reaktif protein, eritrosit sedimantasyon hızı, ince iğne aspirasyon biyopsisi, lenfoma

Address for Correspondence: Esra Turan Erkek, Kartal Dr. Lütfi Kırdar Training and Research Hospital, Clinic of Hematology, ìstanbul, Turkey E-mail: dresraturan@gmail.com ORCID: orcid.org/0000-0001-7206-6699 Received: 01.12.2020 Accepted: 27.04.2021

Cite this article as: Turan Erkek E, Bozkurt OF, Demirağ Evman M. Erythrocyte Sedimentation Rate May Predict Diagnosis of Lymphoma Without Fine-needle Aspiration Biopsy: A Retrospective Study. Bagcilar Med Bull 2021;6(2):190-197

(-Copyright 2021 by the Health Sciences University Turkey, Bagcilar Training and Research Hospital Bagcilar Medical Bulletin published by Galenos Publishing House. 


\section{Introduction}

Lymphomas are neoplasms of lymphoid cells and often begin in lymph nodes and spread to lymphoid tissues in the spleen, gastrointestinal system, liver and bone marrow $(1,2)$. These clonal neoplasms arise from different differentiation steps of immature or mature B-cells, T-cells or natural killer cells (1). There are two main subtypes; nonHodgkin lymphoma (NHL) and Hodgkin lymphoma (HL). Global cancer data estimates show that $2.8 \%$ of cancers are NHL and $0.4 \%$ are HL (3).

Inflammation is the basis of various processes in cancer pathogenesis, including the formation and spread of cancer cells (4). The role of inflammation in the formation and spread of cancer has been studied for a long time and various types of cancer have been shown to develop on the basis of chronic inflammation $(5,6)$. In other words, conditions suitable for cancer development may be provided by the presence of chronic inflammation (4). Similar to other types of cancer, the pathogenesis of lymphoma has also been associated with inflammation $(7,8)$. Many markers have been identified in attempts to determine or assess inflammatory activity in the context of cancer, including lymphoma. Some studies have come upon the conclusion that these parameters may be utilized in the prediction or assessment of diagnosis, prognosis or response to treatment in lymphoma (9-13).

Surgical excisional biopsy (SEB) of the lymph node is recommended for the definitive diagnosis of lymphoma in current guidelines (14-17). Although fine needle aspiration biopsy (FNAB) performed for lymphoma diagnosis may provide conclusive results, its results may be insufficient for a definitive diagnosis, necessitating SEB. (18). Additionally, performing FNAB before SEB may be a cause of delay in diagnosis and could lead to the exposure to invasive interventions twice. If laboratory tests, which are routinely checked in all patients prior to FNAB, can direct clinicians to SEB without FNAB, an extra invasive procedure may not be needed. For this reason, in this study, we aimed to assess the relationship between routine blood values recorded before FNAB of the cervical lymph nodes and final diagnosis in patients who had required SEB of cervical lymph nodes due to inconclusive results with FNAB.

\section{Materials and Methods}

\section{Patient Group}

In this study, the data of patients who could not be diagnosed via FNAB and who underwent SEB of the cervical lymph node between March 2014 and March 2019 in Istanbul Kartal Dr. Lütfi Kırdar Training and Research Hospital Otolaryngology Clinic were evaluated retrospectively. All patients examined were 18 years old or older. Data were collected between March 2019 and September 2020. Permission was obtained from the Clinical Research Ethics Committee of Kartal Dr. Lütfi Kurdar Training and Research Hospital to conduct the study $(2019 / 514 / 148 / 6)$.

According to the sample size results calculated using laboratory values in the study of Okumura et al. (19), it was determined that there should be 44 individuals in each group to provide a power of $80 \%$ with $5 \%$ alpha error.

\section{Exclusion Criteria}

1- Patients with a previous diagnosis of lymphoma and having undergone SEB for recurrence verification without the use of FNAB.

2- Patients who were previously diagnosed with solid organ tumor and had undergone a biopsy for the assessment of metastasis.

\section{Determination of Groups}

According to the definitive diagnosis determined by SEB, the cases were divided into 3 groups as follows: 1) benign, 2) other malignancies, 3) lymphoma.

\section{Variables of Interest}

The age, gender and laboratory measurements of the patients recorded before FNAB were examined. The laboratory measurements examined were C-reactive protein (CRP), erythrocyte sedimentation rate (ESR), alanine aminotransferase (ALT), aspartate aminotransferase (AST), lactate dehydrogenase (LDH) and hemoglobin levels and white blood cell, neutrophil, lymphocyte and platelet counts.

Patients who apply to our clinic with lymphadenopathy in the neck are first evaluated by ultrasonography and the size, number and characteristics of the lymph node are analyzed. If there is a finding in favor of infection in the patient, the patient is re-evaluated after 2 weeks of antibiotic treatment. In addition, if there are some infections (brucellosis, tuberculosis, etc.) in the history, they are referred to the infection department. If no response is obtained about lymphadenopathy after the antibiotic treatment given to the patient, planning is made for more detailed evaluations. If malignancy is suspected, detailed blood tests are requested (hemogram, sediment, CRP, serology) and peripheral smear, PPD skin test and 
chest radiography are added to the tests. If the suspicion of malignancy persists as a result of all these examinations, FNAB is requested first. In cases where there is a strong possibility of lymphoma in the patient, lymph node excision is applied to the patient by taking the opinion of the hematology clinic.

In our hospital, excisional biopsies are performed in the operating room under sterile conditions and most of the patients are kept under observation in our service overnight. Meanwhile, intravenous antibiotic therapy is administered. Our patients discharged on the evening of the operation are sent home with oral antibiotics and are called for control the next day. There was no patient complicated with infection among the patients who underwent excisional biopsy. Before the procedure, patients with active infection (acute lymphadenitis) were not operated without antibiotic treatment. Sometimes, patients with tuberculosis may have lymph nodes fistulized to the skin, but no such patient was found in our study.

\section{Statistical Analysis}

All analyses were performed on SPSS v21 (SPSS Inc., Chicago, IL, USA). For the normality check, the ShapiroWilk test was used. Data were given as mean \pm standard deviation or median ( $1^{\text {st }}$ quartile- $3^{\text {rd }}$ quartile) for continuous variables according to normality of distribution and as frequency (percentage) for categorical variables. Normally distributed variables were analyzed with One-Way analysis of variances (ANOVA). Non-normally distributed variables were analyzed with the Kruskal-Wallis test. Pairwise comparisons of these variables were performed with the Bonferroni correction method. Categorical variables were analyzed with chi-square tests. Diagnostic performances of the variables were evaluated with the receiver operating characteristic (ROC) curve analysis. The best cut-off value was determined based on the highest value obtained in ROC curve analysis according to Youden's index. $p<0.05$ values were accepted as statistically significant results.

\section{Results}

The benign, other malignancies and lymphoma groups were comprised of 62 (27 males), 37 (28 males) and 47 (24 males) patients, respectively. When the presentation symptoms were examined among the groups, the three most common symptoms encountered in lymphoma patients were weight loss $(25.5 \%)$, fever $(21.3 \%)$ and night sweats $(8.5 \%)$. In the group of patients with other malignancies, the three most common presenting symptoms were weight loss (32.4\%), oral intake-swallowing difficulty (21.6\%) and hoarseness (18.9\%) (Table 1).

Among other malignancies, the three most common malignancies were squamous cell carcinoma (29.7\%), carcinoma metastasis (16.2\%) and malignant mesenchymal tumor $(10.8 \%)$.

Although age was similar in all three groups $(\mathrm{p}=0.053)$, gender distribution demonstrated a significant difference in 3-group comparison $(\mathrm{p}=0.007)$. Post-hoc corrections showed that only the other malignancies group had a significant difference from the other two groups, with a higher percentage of males.

The frequency of males in the other malignancies group was significantly higher compared to the other two groups (male percentages were $43.55 \%, 75.68 \%$ and $51.06 \%$, respectively, $\mathrm{p}=0.007$ ).

Compared to the benign group, hemoglobin level was significantly lower in the lymphoma group (mean hemoglobin levels were 13.33, 12.80 and 11.93, respectively, $\mathrm{p}=0.003$ ) (Graphic 1), while neutrophil level was significantly higher in the other malignancies group (median neutrophil levels were 4.35, 5.9 and 4.9, respectively, $\mathrm{p}=0.017$ ).

Compared to the other two groups, CRP level was significantly lower in the benign group (median CRP levels were 5, 17 and 15, respectively, $\mathrm{p}=0.001$ ) (Graphic 2).

The ESR level of the lymphoma group was significantly higher than that of the other groups. In addition, the ESR level of the other malignancies group was higher than that of the benign group (Graphic 3). The only parameter with significant pairwise differences among all three groups was ESR (median ESR levels were 12, 24 and 52, respectively, $\mathrm{p}<0.001$ ) (Table 2).

\begin{tabular}{lll} 
Table 1. Distribution of symptoms at presentation in groups \\
& $\begin{array}{l}\text { Other malignancies } \\
\mathbf{n}(\%)\end{array}$ & $\begin{array}{l}\text { Lymphoma } \\
\mathbf{n}(\%)\end{array}$ \\
\hline Weight loss & $12(32.4)$ & $12(25.5)$ \\
Fever & $1(2.7)$ & $10(21.3)$ \\
Night sweats & - & $4(8.5)$ \\
Oral intake-swallowing & $8(21.6)$ & - \\
difficulties & & \\
Hoarseness & $7(18.9)$ & - \\
Mass in the neck & $1(2.7)$ & - \\
Stuffy nose & $1(2.7)$ & - \\
Nasal and postnasal drip & $1(2.7)$ & - \\
Respiratory distress & $1(2.7)$ & $1(2.1)$ \\
\hline & &
\end{tabular}


The ROC analysis revealed that ESR had $70.21 \%$ sensitivity, $75.76 \%$ specificity and $73.97 \%$ accuracy for the discrimination of lymphoma from other malignancies and benign lesions with a cut-off value of $>35.5 \mathrm{~mm} / \mathrm{hr}$ (higher values in favor of lymphoma) (area under the curve $=0.784$, 95\% confidence interval: 0.708-0.861, p <0.001) (Graphic 4).

White blood cell ( $\mathrm{p}=0.783)$, neutrophil $(\mathrm{p}=0.700)$, lymphocyte $\quad(\mathrm{p}=0.431)$, hemoglobin $\quad(\mathrm{p}=0.144), \quad \mathrm{LDH}$ $(\mathrm{p}=0.144)$, AST ( $\mathrm{p}=0.711)$, ALT ( $\mathrm{p}=0.116)$, and CRP $(\mathrm{p}=0.382)$ levels were found to be similar between the subtypes of lymphoma. Platelet (median levels were 342, 237.5, 207, and 203.5, respectively, $\mathrm{p}=0.007$ ) and ESR (median levels

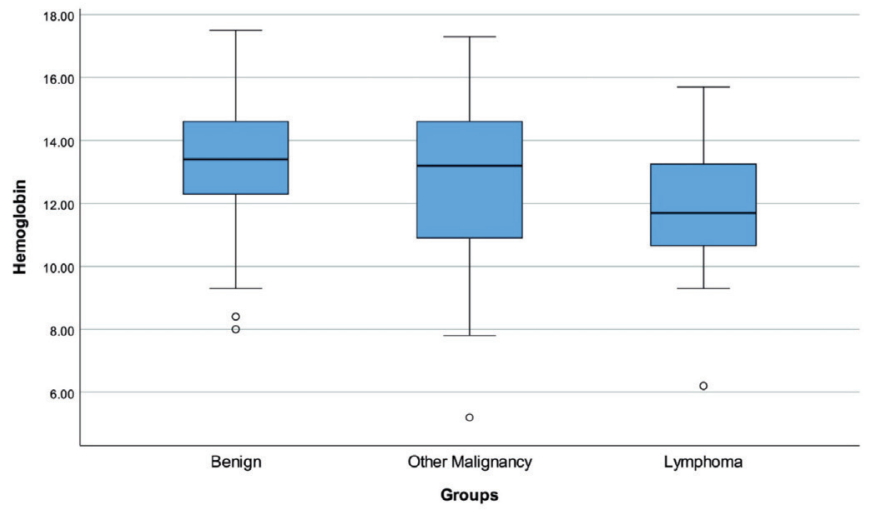

Graphic 1. Box-plot of the hemoglobin values were $78,52.5,28$, and 36 , respectively, $\mathrm{p}=0.019$ ) values of patients diagnosed with HL were statistically significantly higher than in those with indolent lymphoma (Table 3).

\section{Discussion}

Diagnosis of lymphoma may be difficult for both patients and clinicians, especially considering the procedures required for diagnosis. In this study, which examined the possibility of limiting invasive procedures during the lymphoma diagnosis process by taking laboratory measurements into consideration, we found that hemoglobin levels were lower and CRP and ESR levels

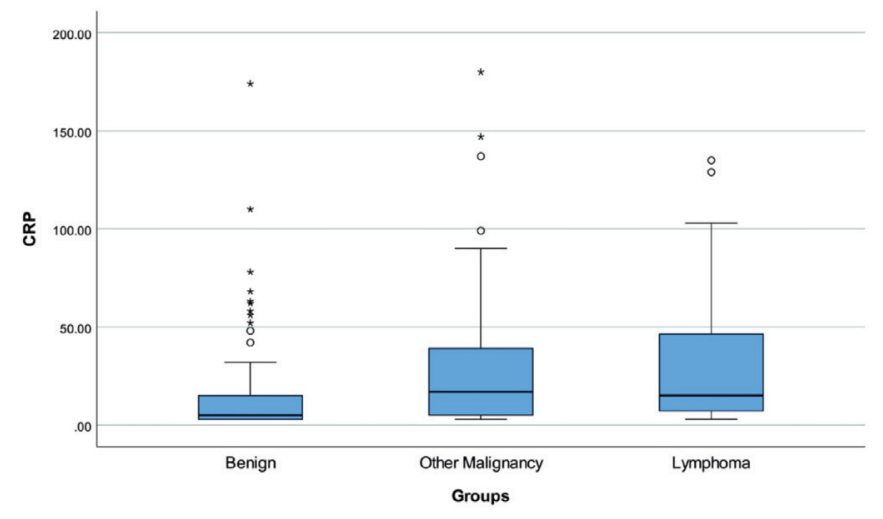

Graphic 2. Box-plot of the CRP values

CRP: C-reactive protein

Table 2. Summary of patient characteristics and laboratory measurements

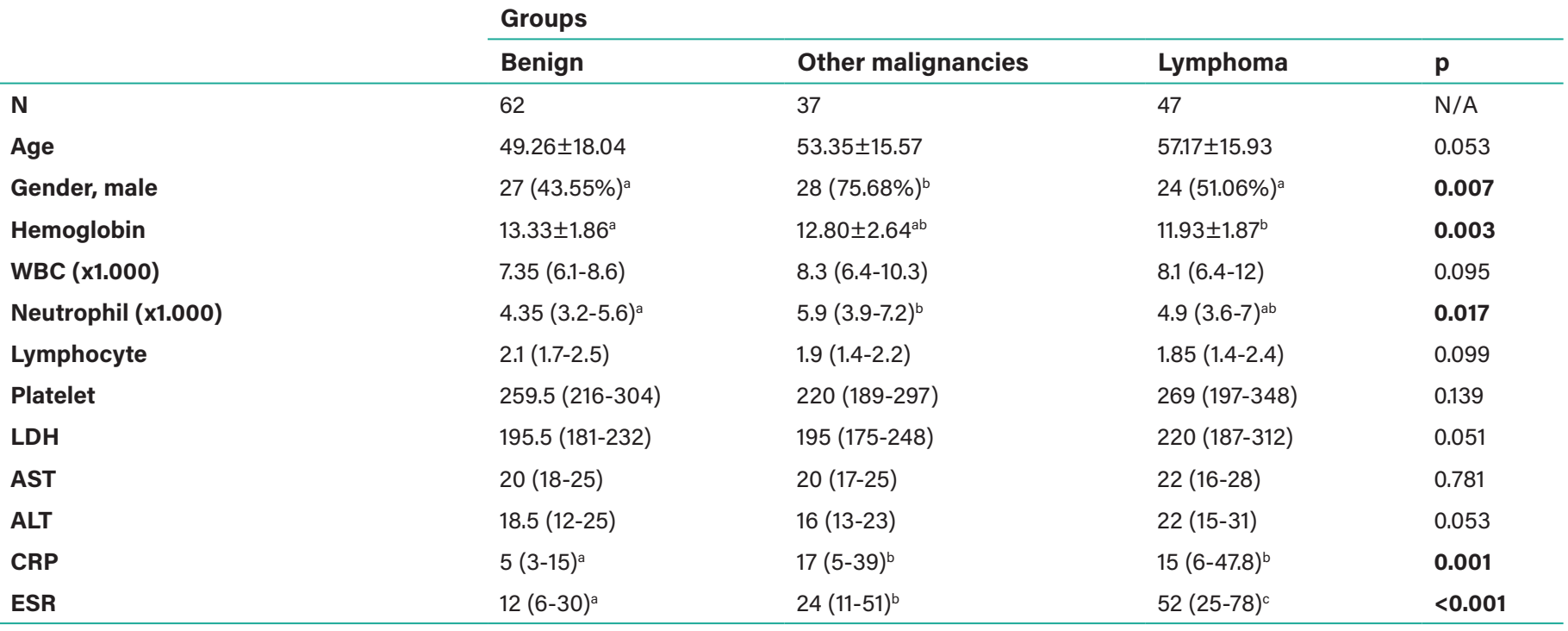

ALT: Alanine aminotransferase, AST: Aspartate aminotransferase, CRP: C-reactive protein, ESR: Erythrocyte sedimentation rate, LDH: Lactate dehydrogenase, WBC: White blood cell

Data are given as mean \pm standard deviation or median ( $1^{\text {st }}$ quartile- $3^{\text {rd }}$ quartile) for continuous variables according to the normality of distribution and as frequency (percentage) for categorical variables.

Same letters denote the lack of statistically significant difference between the groups 
were higher in the lymphoma group compared to benign cases. Furthermore, although CRP levels showed lower inflammatory activity in the benign group, our results revealed that ESR was the only parameter that could differentiate lymphoma cases from both the benign group and the other malignancies group. ESR level was significantly higher in lymphoma cases.

ESR can be simply defined as the rate at which erythrocytes settle towards the bottom of the tube in anticoagulated blood. Despite its simplicity, ESR is a widely used inflammation marker in addition to its role in other purposes, such as determining acute phase response, tissue damage and response to treatment (20). Based on these features, ESR has been investigated to predict the diagnosis and prognosis of various cancer types, including lymphoma. In a study examining the predictability of various cancer diagnoses by assessing elevated inflammatory markers (adjusted for age and sex), Watson

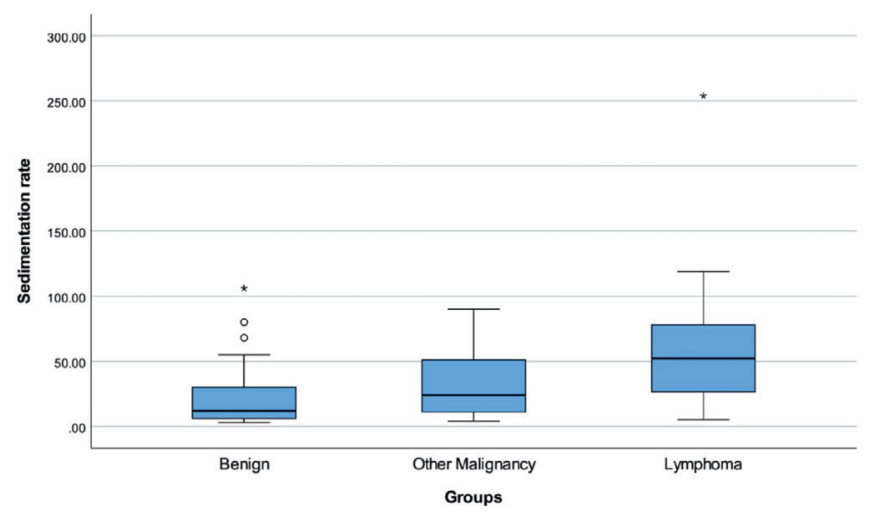

Graphic 3. Box-plot of the sedimentation rates et al. (21) showed that CRP had $46.1 \%$ sensitivity and $75.4 \%$ specificity and ESR had $43.6 \%$ sensitivity and $75.6 \%$ specificity. Liu et al. (22) investigated the use of ESR and CRP in the differential diagnosis of intestinal lymphoma and active Crohn's disease. They reported $60.0 \%$ sensitivity and $80.0 \%$ specificity for an ESR threshold of $>24.2 \mathrm{~mm} / \mathrm{hr}$ and $62.1 \%$ sensitivity and $96.0 \%$ specificity for a CRP threshold of $>19.7 \mathrm{mg} / \mathrm{dL}$ in the diagnosis of lymphoma (22). In our study, a $>35.5 \mathrm{~mm} / \mathrm{hr}$ cut-off for ESR was found to have a sensitivity and specificity of over $70 \%$ in distinguishing lymphoma from other malignancies and benign lesions. In previous studies, the levels of inflammation markers in the other malignancies, benign pathologies and lymphoma

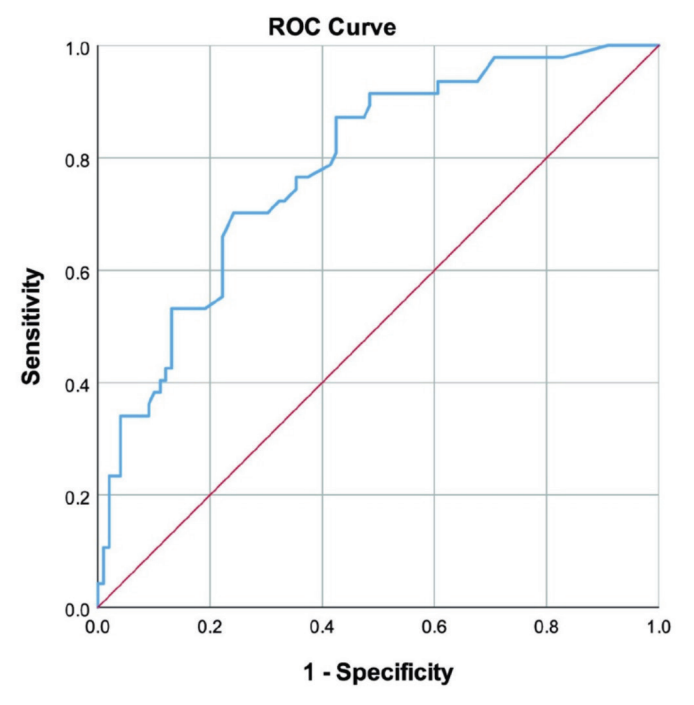

Diagonal segments are produced by ties.

Graphic 4. ROC curve of the sedimentation rate to discriminate lymphoma from other tumors

Table 3. Distribution of laboratory measurements according to lymphoma subtypes

\begin{tabular}{|c|c|c|c|c|c|}
\hline & Hodgkin lymphoma & $\begin{array}{l}\text { Diffuse large B-cell } \\
\text { lymphoma (DLBCL) }\end{array}$ & Indolent lymphoma & T-cell lymphoma & $\mathbf{p}$ \\
\hline WBC & $8.250(6.325-12.425)$ & $8.100(6.350-9.125)$ & $9.100(6.400-15.600)$ & $7.550(5.270-12.275)$ & 0.783 \\
\hline Lymphocyte & $1.925(1.445-2.370)$ & $1 . .570(1250-2.625)$ & $2.400(1.130-7.600)$ & $1.850(1627.5-2072.5)$ & 0.431 \\
\hline Hemoglobin & $11.2(10.6-12.9)$ & $11.7(10.3-13.1)$ & $12.7(9.9-14.1)$ & $13.4(13.2-14.1)$ & 0.144 \\
\hline Platelet & $342,000(265,000-449,000)^{a}$ & $237,500(157,250-296,000)^{\mathrm{ab}}$ & $207,000(125,000-344,000)^{b}$ & $203,500(176,750-233,250)^{\mathrm{ab}}$ & 0.007 \\
\hline AST & $19.5(16.3-27)$ & $22.5(15.7-37.5)$ & $24(19-34)$ & $16(15.2-29.5)$ & 0.711 \\
\hline ALT & $21(12.8-28.5)$ & $28.5(15-37)$ & $25(17-39)$ & $14.5(10.7-19)$ & 0.116 \\
\hline ESR & $78(40.5-88.3)^{\mathrm{a}}$ & $52.5(28-71.7)^{\mathrm{ab}}$ & $28(11.4-56)^{b}$ & $36(17-59.5)^{a b}$ & 0.019 \\
\hline CRP & $22.6(9.6-66.2)$ & $16.6(8.5-27.5)$ & $9.6(3.3-27)$ & $11.9(5.1-69.9)$ & 0.382 \\
\hline
\end{tabular}

WBC: White blood cell, LDH: Lactate dehydrogenase, ALT: Alanine aminotransferase, AST: Aspartate aminotransferase, ESR: Erythrocyte sedimentation rate, CRP: C-reactive protein

Data are given as median ( $1^{\text {st }}$ quartile $-3^{\text {rd }}$ quartile) for variables 
groups were not examined; whereas, we found that these groups were similar in terms of other parameters. In addition, various studies have shown that ESR value is characteristically higher in women and increases with age, regardless of other variables (23). Therefore, the higher frequency of female gender in the lymphoma group in our study may be one of the reasons causing higher ESR in this group; however, it was noted that the benign and lymphoma groups were similar with regard to gender distribution.

Another parameter considered as an indicator of inflammation is CRP (24). Allin et al. (25) showed that the probability of detecting any type of cancer increased 1.3 times in cases with increased CRP. In a review study, although the cause and effect relationship was not clarified, it was suggested that the increase in CRP was associated with cancer diagnosis and prognosis in different types of cancer (26). In a systematic review examining the relationship between CRP level and cancer, Heikkilä et al. (27) reported that increased CRP in cancer cases was shown in previous studies, but as a result of prospective studies, the causal relationship between CRP and cancer could not be clearly revealed. In different studies, it has been shown that CRP elevation is an important biomarker in the diagnosis and follow-up of various cancer types $(28,29)$. The CRP-lymphoma relationship has been examined in other previous studies. Wieland et al. (30) reported that $64 \%$ of the patients diagnosed with HL had elevated CRP level at the time of diagnosis (with regard to reference range) and that CRP levels changed in relation with the severity of disease. Consistent with previous studies, the CRP level, which is among the parameters examined in our study, was found to be significantly lower in the benign group than in the other groups. Although a causal relationship could not be demonstrated in this study, it was thought that high CRP was caused by the increase in inflammatory activity due to the course of disease.

Another area of use of inflammatory markers is to evaluate the prognosis of disease and the response to treatment. Hamed Anber et al. (12) have reported that inflammatory markers above the reference values negatively affect prognosis and response to treatment in patients with lymphoma. Wu et al. (13) have suggested that the ESR value is associated with the prognosis of the disease in diffuse large B-cell lymphoma cases and that it can be used to predict the likelihood of successful treatment and recurrence. Kawaguchi et al. (31) reported that progressionfree survival was shorter in follicular lymphoma cases with a CRP level above $5 \mathrm{mg} / \mathrm{dL}$. In addition, many different studies have shown that increasing CRP level can predict diagnosis and progression in different types of lymphoma (32-34). Considering the studies conducted on this subject, it is thought that CRP and ESR levels may be important in predicting the severity of the disease, as well as directing clinicians in their approach to the diagnosis of other malignancies or lymphoma.

The diagnosis process of lymphoma patients generally depends on the approach of surgical branches. For this reason, it is important that the clinicians performing SEB are able to accurately assess patients from the beginning in terms of differentiating lymphoma, solid tumors and other diagnoses. Although the change in the laboratory values of lymphoma patients may be easily recognized by hematologists, the same familiarity may not be observed among surgeons. Although expensive imaging methods such as positron emission tomography and computed tomography may provide important clues in terms of staging and spread of lymphoma and solid organ tumors, biopsy is still essential for diagnosis (14-17). Additionally, the accessibility of these imaging methods is limited, their widespread use is unnecessary, and such approaches will increase diagnostic and treatment costs. However, biochemical parameters and hemogram results are laboratory measurements that are routinely evaluated in almost every patient.

The grouping of different malignancies or cases with different lymphoma types under the same category is an important limitation of our study because the levels of inflammatory markers may vary in different types of cancer. Analyses specific to the type of cancer may be useful in future studies. Lifestyle and behaviors (smoking, alcohol consumption, physical activity) and the presence of other chronic diseases may alter the levels of inflammatory markers (23); however, these were not questioned, representing another limitation. Additionally, the possible influence of disease stage on the outcomes was not studied. Studies to be carried out taking these parameters into consideration will reinforce the accuracy of our results. Due to the design of our study, it could not be determined whether the increase in inflammation markers was the cause or result of the pathology. Prospective studies can be useful in this respect. The higher prevalence of males in the other malignancies group may have affected the results; however, the benign and lymphoma groups were similar with regard to sex distribution. 


\section{Conclusion}

It was determined that ESR, which is one of the laboratory measurements evaluated before FNAB, was an important biomarker that could have a role in directing clinicians to the diagnosis of lymphoma. Although ESR is non-specific, which limits its use in asymptomatic patients, it may be valuable in reducing repetitive invasive procedures among symptomatic patients (weight loss, fever, night sweats, etc.) who require cervical lymph node biopsy for diagnosis. When ESR is detected above a certain level, it may be feasible to prefer SEB directly (without FNAB analysis). Conducting prospective studies specific to the type and stage of lymphomas will be beneficial for the use of such parameters in early diagnosis and could reduce the number of invasive procedures. Additionally, it may be beneficial to further ascertain the role of inflammatory markers in the prediction of lymphoma prognosis and/or response to treatment.

\section{Ethics}

Ethics Committee Approval: The local ethical committee of our university approved the study protocol and all participants signed the written informed consent form.

Informed Consent: Written consent was obtained.

Peer-review: Externally and internally peer-reviewed.

\section{Authorship Contributions}

Concept: E.T.E., O.F.B., Design: E.T.E., M.D.E., Data Collection or Processing: O.F.B., M.D.E., Analysis or Interpretation: E.T.E., M.D.E., Literature Search: E.T.E., O.F.B., Writing: E.T.E., O.F.B., M.D.E.

Conflict of Interest: No conflict of interest was declared by the authors.

Financial Disclosure: The authors declared that this study has received no financial support.

\section{References}

1. Bispo JAB, Pinheiro PS, Kobetz EK. Epidemiology and etiology of leukemia and lymphoma. Cold Spring Harb Perspect Med 2020;10(6):a034819.

2. Chiu BC-H, Hou N. Epidemiology and etiology of non-hodgkin lymphoma. Non-Hodgkin Lymphoma: Springer, 2015:1-25.

3. Bray F, Ferlay J, Soerjomataram I, Siegel RL, Torre LA, Jemal A. Global cancer statistics 2018: GLOBOCAN estimates of incidence and mortality worldwide for 36 cancers in 185 countries. CA Cancer J Clin 2018;68(6):394-424.

4. ElinavE,NowarskiR, ThaissCA,HuB,JinC,FlavellRA.Inflammationinduced cancer: crosstalk between tumours, immune cells and microorganisms. Nat Rev Cancer 2013;13(11):759-771.
5. Hanahan D, Weinberg RA. Hallmarks of cancer: the next generation. Cell 2011;144:646-674.

6. Hagerling C, Casbon A-J, Werb Z. Balancing the innate immune system in tumor development. Trends Cell Biol 2015;25(4):214220 .

7. Sagaert X, Van Cutsem E, De Hertogh G, Geboes K, Tousseyn T. Gastric MALT lymphoma: a model of chronic inflammationinduced tumor development. Nat Rev Gastroenterol Hepatol 2010;7(6):336-346.

8. Loong F, Chan AC, Ho BC, Chau YP, Lee HY, Cheuk W, et al. Diffuse large B-cell lymphoma associated with chronic inflammation as an incidental finding and new clinical scenarios. Mod Pathol 2010;23(4):493-501.

9. Makgoeng SB, Bolanos RS, Jeon CY, Weiss RE, Arah OA, Breen EC, et al. Markers of immune activation and inflammation and nonHodgkin lymphoma: a meta-analysis of prospective studies. JNCI cancer spectrum 2018;2(4):pky082. doi: 10.1093/jncics/pky082.

10. Rotaru I, Gaman GD, Stanescu C, Gaman AM. Evaluation of parameters with potential prognosis impact in patients with primary gastric diffuse large B-cell lymphoma (PG-DLBCL). Rom J Morphol Embryol 2014;55(1):15-21.

11. Grivennikov SI, Greten FR, Karin M. Immunity, inflammation and cancer. Cell 2010;140(6):883-899.

12. Hamed Anber N, El-Sebaie AH, Darwish NH, Mousa SA, Shamaa SS. Prognostic value of some inflammatory markers in patients with lymphoma. Biosci Rep 2019;39(3):BSR20182174. doi: 10.1042/ BSR20182174.

13. Wu S, Zhou Y, Hua H-Y, Zhang Y, Zhu W-Y, Wang Z-Q, et al. Inflammation marker ESR is effective in predicting outcome of diffuse large B-cell lymphoma. BMC Cancer 2018;18(1):997.

14. Tilly H, Gomes da Silva M, Vitolo U, Jack A, Meignan M, LopezGuillermo A, et al. Diffuse large B-cell lymphoma (DLBCL): ESMO Clinical Practice Guidelines for diagnosis, treatment and followup. Ann Oncol 2015;26(Suppl 5):v116-v125. doi: 10.1093/annonc/ mdv304.

15. Dreyling M, Ghielmini M, Marcus R, Salles G, Vitolo U, Ladetto M. Newly diagnosed and relapsed follicular lymphoma: ESMO Clinical Practice Guidelines for diagnosis, treatment and followup. Ann Oncol 2014;25(Suppl 3):iii76-iii82.

16. Eichenauer DA, Engert A, André M, Federico M, Illidge T, Hutchings M, et al. Hodgkin's lymphoma: ESMO Clinical Practice Guidelines for diagnosis, treatment and follow-up. Ann Oncol 2014;25(Suppl 3):iii70-iii75. doi: 10.1093/annonc/mdu181.

17. Dreyling M, Campo E, Hermine O, Jerkeman M, Le Gouill S, Rule S, et al. Newly diagnosed and relapsed mantle cell lymphoma: ESMO Clinical Practice Guidelines for diagnosis, treatment and followup. Ann Oncol 2017;28(Suppl 4):iv62-iv71. doi: 10.1093/annonc/ mdx223.

18. Johl A, Lengfelder E, Hiddemann W, Klapper W, German Low-grade Lymphoma Study Group (GLSG). Core needle biopsies and surgical excision biopsies in the diagnosis of lymphoma-experience at the Lymph Node Registry Kiel. Ann Hematol 2016;95(8):1281-1286.

19. Okumura Y, Nomura K, Kikuchi T, Suzuki T, Hidaka H, Ogawa T, et al. Clinical factors indicating the presence of malignant lymphoma before lymph node dissection. Acta Otolaryngol 2015;135(5):513518.

20. Bochen K, Krasowska A, Milaniuk S, Kulczynska M, Prystupa A, Dzida G. Erythrocyte sedimentation rate-an old marker with 
new applications. Journal of Pre-clinical and Clinical Research 2011;5(2):50-55.

21. Watson J, Salisbury C, Banks J, Whiting P, Hamilton W. Predictive value of inflammatory markers for cancer diagnosis in primary care: a prospective cohort study using electronic health records. $\mathrm{Br}$ J Cancer 2019;120(11):1045-1051.

22. Liu S, Ren J, Wu X, Ren H, Yan D, Wang G, et al. Preliminary casecontrol study to evaluate diagnostic values of C-reactive protein and erythrocyte sedimentation rate in differentiating active Crohn's disease from intestinal lymphoma, intestinal tuberculosis and Behcet's syndrome. Am J Med Sci 2013;346(6):467-472.

23. Alende-Castro V, Alonso-Sampedro M, Vazquez-Temprano N, Tuñez C, Rey D, García-Iglesias C, et al. Factors influencing erythrocyte sedimentation rate in adults: new evidence for an old test. Medicine (Baltimore) 2019;98(34):e16816.

24. Sproston NR, Ashworth JJ. Role of C-reactive protein at sites of inflammation and infection. Front Immunol 2018;9:754.

25. Allin KH, Bojesen SE, Nordestgaard BG. Baseline C-reactive protein is associated with incident cancer and survival in patients with cancer. J Clin Oncol 2009;27(13):2217-2224.

26. Allin KH, Nordestgaard BG. Elevated C-reactive protein in the diagnosis, prognosis and cause of cancer. Crit Rev Clin Lab Sci 2011;48(4):155-170.

27. Heikkilä K, Ebrahim S, Lawlor DA. A systematic review of the association between circulating concentrations of $\mathrm{C}$ reactive protein and cancer. J Epidemiol Community Health 2007;61(9):824833.
28. Xu H-J, Ma Y, Deng F, Ju W-B, Sun X-Y, Wang H. The prognostic value of C-reactive protein/albumin ratio in human malignancies: an updated meta-analysis. Onco Targets Ther 2017;10:3059-3070.

29. Bień E, Balcerska A. [Clinical significance of erythrocyte sedimentation rate, C-reactive protein and serum lactate dehydrogenase levels in the diagnosis, prognosis and treatment monitoring of children suffering from cancer.] Med Wieku Rozwoj 2004;8(4 Pt 2):1081-1089.

30. Wieland A, Kerbl R, Berghold A, Schwinger W, Mann G, Urban C. C-reactive protein (CRP) as tumor marker in pediatric and adolescent patients with Hodgkin disease. Med Pediatr Oncol 2003;41(1):21-25.

31. Kawaguchi Y, Saito B, Nakata A, Matsui T, Sasaki Y, Shimada S, et al. Elevated C-reactive protein level is associated with poor prognosis in follicular lymphoma patients undergoing rituximab-containing chemotherapy. Int J Hematol 2020;112(3):341-348.

32. Troppan K, Schlick K, Deutsch A, Melchardt T, Egle A, Stojakovic T, et al. C-reactive protein level is a prognostic indicator for survival and improves the predictive ability of the R-IPI score in diffuse large B-cell lymphoma patients. Br J Cancer 2014;111(1):55-60.

33. Li Y-J, Li Z-M, Xia Y, Huang J-J, Huang H-Q, Xia Z-J, et al. Serum C-reactive protein (CRP) as a simple and independent prognostic factor in extranodal natural killer/T-cell lymphoma, nasal type. PloS One 2013;8(5):e64158.

34. Du J, Wang Q, He B, Liu P, Chen JY, Quan H, et al. Association of mean platelet volume and platelet count with the development and prognosis of ischemic and hemorrhagic stroke. Int J Lab Hematol 2016;38(3):233-239. 